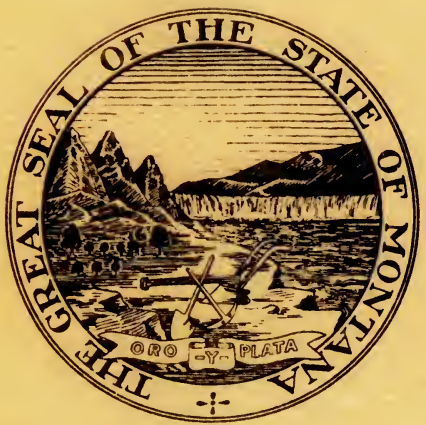

THOMAS L, JUDGE, GOVERNOR

MONTANA ENERGY ADVISORY COUNCIL STATE CAPITOL

HELENA, MONTANA 59601 

MONTANA STATE LIBRARY

S 631.37 E13e c.1 Wheeling

Energy coneumption by forestry end egric

30864000943665

ENERGY CONSUMPTION BY FORESTRY AND

AGRICULTURE IN MONTANA

Prepared By

Terry Wheeling

Energy Data Specialist

MONTANA ENERGY ADVISORY COUNCIL

Staff Paper 76-3

July 6, 1976

Haceld, vis ad.d 1.96 

Energy Consumption by Forestry and Agriculture in Montana

Various estimates of fuels consumption in the forestry and agricultural sectors in Montana were gathered and reviewed to obtain order-of-magnitude estimates of energy use in these areas. The data at this time are very approximate and show little or no breakdown by process or function.

A brief summary of energy consumption estimates by fuel type is presented in Table 1 . In general, natural gas and electricity use data in the forestry sector can be considered firm data, whereas petroleum products use in either sector is very crude. Use of natural gas and electricity for agricultural purposes other than irrigation, and for all use of LPG in agriculture are not included in Table 1.

Table 1

Approximate Annual Consumption of Selected Fuels by the Forestry and Agriculture Sectors in Montana

\begin{tabular}{|c|c|c|c|c|c|}
\hline Sector & $\begin{array}{c}\text { (1) } 1 \\
\text { Natural } \\
\text { Gas } \\
\text { (MMCF) } \\
\end{array}$ & $\begin{array}{l}\text { (2) } \\
\text { Electricity } \\
\text { (million KWH) } \\
\end{array}$ & $\begin{array}{l}\text { (3) } 2 / \\
\text { Gasoline } \\
\text { (million } \\
\text { gallons) } \\
\end{array}$ & $\begin{array}{c}\text { (4) } \\
\text { Diesel Fuel } \\
\text { (million } \\
\text { gallons) } \\
\end{array}$ & $\begin{array}{l}\text { Total of } \\
(1)-(4) \\
\left(10^{12} \text { BTU }\right)\end{array}$ \\
\hline Forestry & 5,600 & 390.0 & $0.9-2.0$ & $4.6-7.9$ & $7.7-8.3$ \\
\hline Agriculture & $6.6^{3}$ & $.18^{\underline{3}}$ & $30.0-40.0$ & $25.0-35.0$ & $7.25-10.0$ \\
\hline
\end{tabular}

1/ Data are for 1974 .

2/ Data are for 1973 .

3/ Data shown include only energy used for irrigation. 


\section{Forest Sector}

Two estimates were used for gasoline and diesel fuel consumption in timber harvesting and hauling to the first level of processing. First, a study of forestry energy use in Washington state by N. K. Whittlesey (1) was reviewed. Estimates derived in the Washington state study are shown in Table 2; more detailed data from this study are presented in the attachments. Secondly, similar estimates were prepared by Plum Creek Lumber Company for the Montana Fuel Allocation Office (FAO) in 1974. These are also shown in Table 2.

Table 2

Estimates of Fuel Use for Timber Harvesting and Hauling (gallons/1000 board feet)

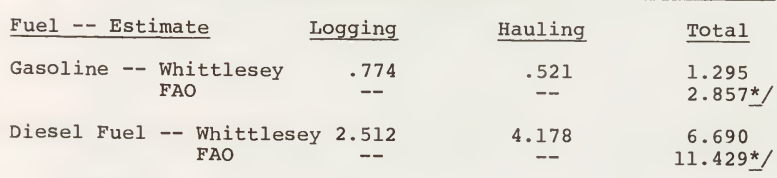

* Estimate originally calculated as one million gallons per 70 million board feet, with 80 percent to diesel fuel and 20 percent to gasoline.

Using these estimates of fuel consumption per unit with the 1973 Montana harvest of 691 million board feet, gives estimates of total fuels used, as shown in Table 3 . 
Table 3

Estimates of Fuels Used for Timber Harvesting and Hauling in Montana in 1973

\begin{tabular}{|c|c|c|c|c|c|}
\hline \multirow[b]{2}{*}{ Activity } & \multirow[b]{2}{*}{1973 Harvest } & \multicolumn{4}{|c|}{$\frac{\text { Estimates of Fuels Consumed (1000 gallons) }}{\text { Fat }}$} \\
\hline & & Gasoline & Diesel Fuel & Gasoline & Diesel Fue] \\
\hline Logging & $691 \times 10^{6} \mathrm{bf}$ & 535 & 1,736 & -- & -- \\
\hline Hauling & $691 \times 10^{6} \mathrm{bf}$ & $\underline{360}$ & 2,887 & -- & -- \\
\hline Total & & $\underline{895}$ & 4,623 & $\underline{1,974}$ & $\underline{7,897}$ \\
\hline
\end{tabular}

Fuels used in the lumber and paper industries in Montana consist mainly of (1) purchased and self-generated electricity, (2) purchased natural gas, and (3) wood and process residues. Some use of residual fuel oil exists, but it is relatively small compared to the other energy inputs. Data for total use of purchased electricity and purchased natural gas is quite good, and is presented in Table 4 , by standard industrial classification (SIC) . 
Table 4

Forestry Sector Consumption of Natural Gas and Purchased Electricity in Montana in 1974 /

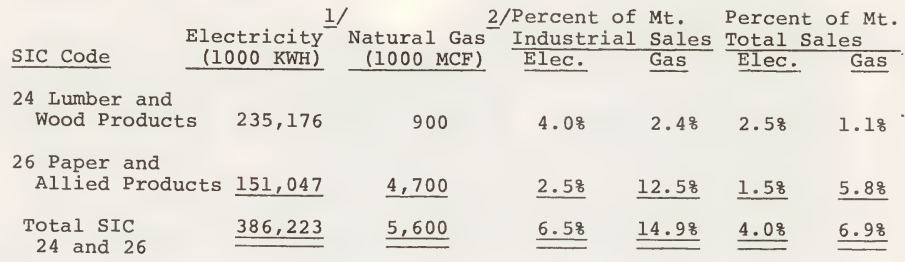

1/ Source: Federal Reserve Bank of Minneapolis. (2)

2/ Source: Gas Requirements Committee of the University of Denver Research Institute. (3)

3/ Forestry manufacturing only.

Complete data is not available for total use of hog fuel as an energy source in Montana forest products industries, however; some examples are presented in Table 5. 
Table 5

Examples of Use of Wood and Process Residues as Energy Sources by Lumber and Paper Industries in Montana in 1974 1)

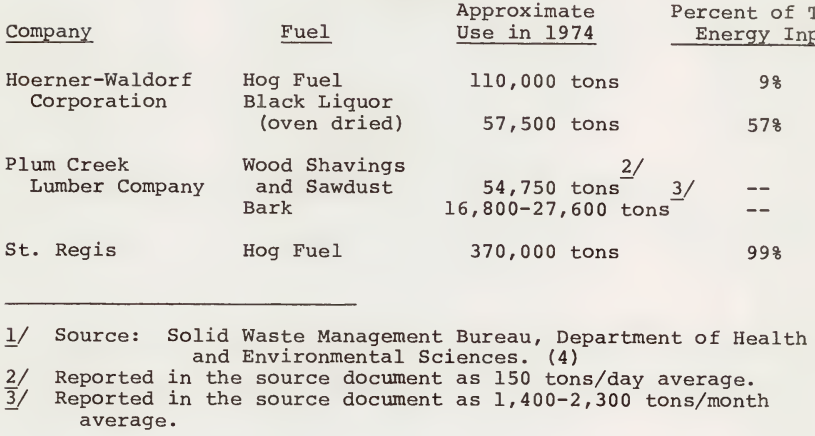

\section{Agriculture}

Due to the decentralized and diverse use of energy within the agricultural sector, data for fuels consumption in Montana is not well developed. Estimates for fuels used for irrigation in Montana in 1974 have been developed by Gordon Sloggett, USDA, ERS, at Oklahoma State University. (5) These estimates are shown in Table 6 . 
Table 6

Acres Irrigated and Energy Consumed for Irrigation in Montana in 1974, by Type of Fuel

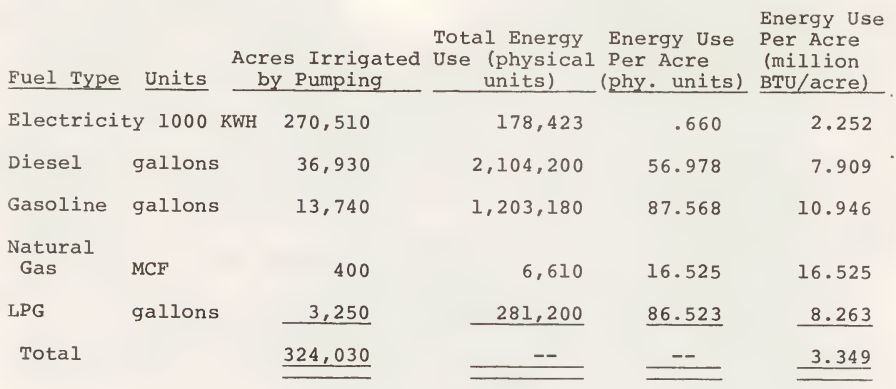

Various estimates of the volume of gasoline and diesel fuel consumed by agriculture for field operations are presented in Table 7 (further documentation of these estimates is contained in the attachments). Operations included within the various estimates are not clearly defined, hence the estimates may not be directly comparable. 
Table 7

Estimates of Montana Agricultural Use of Gasoline and Diesel Fuel for Major Crops in 1973 (1000 gallons)

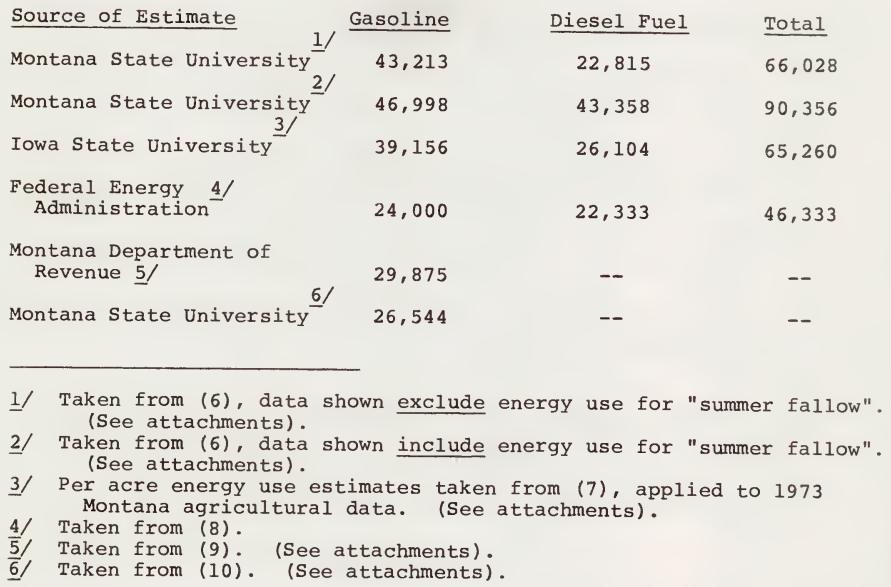




\section{REFERENCES}

(1) Norman K. Whittlesey, Energy Use in Forest Products Industries in Washington, Washington Agricultural Experiment Station, Circular 573, June 1974.

(2) Federal Reserve Bank of Minneapolis, Ninth Federal Reserve District Electric Energy Consumption, monthly.

(3) Gas Requirements Committee, University of Denver Research Institute, Future Gas Consumption of the United States, Volume 6, December 1975.

(4) Energy and Secondary Materials Market Final Report, prepared for the Solid Waste Management Bureau, Montana Department of Health and Environmental Sciences, May 1976.

(5) Gorden Sloggett, Energy Used for Pumping Irrigation Water in the U. S., $197 \overline{4}$, discussion draft, February 1976.

(6) B. Davis, G. Hokanson, and H. Whitaker, Energy Requirements for Crop Production in Montana, Agricultural Economics and Economics Department, Montana State University, Staff Paper 75-11, April 1975.

(7) Dale Hull and H. J. Hirning, "Estimating Farm Fuel Requirements for Crop Production and Livestock Operations", Iowa State Weekly Weather and Crop Bulletin, June 4, 1974.

(8) Federal Energy Administration, Son-of-Strawman Data Series, May $15,1976$.

(9) John Clark, Research Division, Montana Department of Revenue, personal communication, May 1976.

(10) John Braunbeck, Montana Fuel Allocation Office, memorandum concerning information supplied by Dick Meyer, Montana Department of Agriculture, February 27, 1975. 
APPENDIX 
Table 4. Energy use per unit of output in forestry products

\begin{tabular}{|c|c|c|c|c|c|}
\hline Activity & Unit & $\begin{array}{l}\text { Steam or } \\
\text { energy } \\
\text { equiv. } \\
\text { lb/unita,c }\end{array}$ & $\begin{array}{l}\text { Electri- } \\
\text { city } \\
\text { kwh/unita }\end{array}$ & $\begin{array}{l}\text { Gasoline } \\
\text { gal/unit }\end{array}$ & $\begin{array}{l}\text { Diesel } \\
\text { gal/unitb }\end{array}$ \\
\hline $\begin{array}{l}\text { Logging } \\
\text { Hauling logs } \\
\text { Shakes }\end{array}$ & $\begin{array}{l}10^{3} \mathrm{bf} \\
10^{3} \mathrm{bf} \\
\mathrm{Sq}\end{array}$ & 89 & 10.1 & $\begin{array}{l}7 \\
.794 \\
.521\end{array}$ & $\begin{array}{l}2.512 \\
4.178\end{array}$ \\
\hline $\begin{array}{l}\text { Chipboard } \\
\text { Plywood } \\
\text { Veneer }\end{array}$ & $\begin{array}{l}\text { sf }-3 / 4^{\prime \prime} \\
\text { sf-3/8" } \\
\text { sf }\end{array}$ & $\begin{array}{l}2.7 \\
3.5 \\
3.4\end{array}$ & $\begin{array}{l}.30 \\
.18 \\
.29\end{array}$ & & \\
\hline $\begin{array}{l}\text { Lumber sawingd } \\
\text { Lumber sawinge } \\
\text { Lumber drying }\end{array}$ & $\begin{array}{l}b f \\
b f \\
b f\end{array}$ & $\begin{array}{l}2.5 \\
4.0 \\
2.2\end{array}$ & $\begin{array}{l}.25 \\
.30\end{array}$ & & \\
\hline $\begin{array}{l}\text { Pulp unbleached (undried) } \\
\text { Pulp bleached (undried) } \\
\text { Pulp drying }\end{array}$ & $\begin{array}{l}\text { bdt } \\
\text { bdt } \\
\text { bdt }\end{array}$ & $\begin{array}{r}8,000 \\
10,000 \\
5,000\end{array}$ & $\begin{array}{l}140 \\
400 \\
175\end{array}$ & & \\
\hline $\begin{array}{l}\text { Chipping } 1 \\
\text { Paper (average) } \\
\text { Gypsum board }\end{array}$ & $\begin{array}{l}\text { bdt } \\
\text { wt } \\
\text { bdt }\end{array}$ & $\begin{array}{r}13,000 \\
6,000 \\
5,000\end{array}$ & $\begin{array}{l}500 \\
450 \\
100\end{array}$ & & , \\
\hline $\begin{array}{l}\text { Liner board } \\
\text { Fine paper } \\
\text { Misc. (toilet, blotting) }\end{array}$ & $\begin{array}{l}\text { bdt } \\
\text { bdt } \\
\text { bdt }\end{array}$ & $\begin{array}{l}17,000 \\
26,000 \\
19,000\end{array}$ & $\begin{array}{l}500 \\
900 \\
900\end{array}$ & & \\
\hline $\begin{array}{l}\text { Roof felt } \\
\text { Newsprint } \\
\text { Converted paper-mill stock }\end{array}$ & $\begin{array}{l}\text { bdt } \\
\text { bdt } \\
\text { bdt }\end{array}$ & $\begin{array}{r}1,000 \\
14,000 \\
14,000\end{array}$ & $\begin{array}{r}100 \\
1500 \\
200\end{array}$ & & \\
\hline
\end{tabular}

aSource: Dr. Ashley Emery, professor of mechanical engineering, University of Washington.

bFuel requirements for logging and hauling were derived from a survey of loggers and haulers conducted by Matt Anderson, Washington Forest Protective Association.

${ }^{C}$ One pound of steam $=1,350$ BTU consumed, average over all fuels.

${ }^{d}$ Class $A$ and $B$ mill sizes. See table 7 for definition of mill size.

${ }^{e}$ Class $C$ and $D$ mill sizes. See table 7 for definition of mill size. 
Attachment 2, page 1 of 2

from: Energy Requirements for

Crop Production in Montana,

by Bruce Davis, et.al.

TABLE 1

Total Energy Requirements

for Major Crops in Monțana (1973)

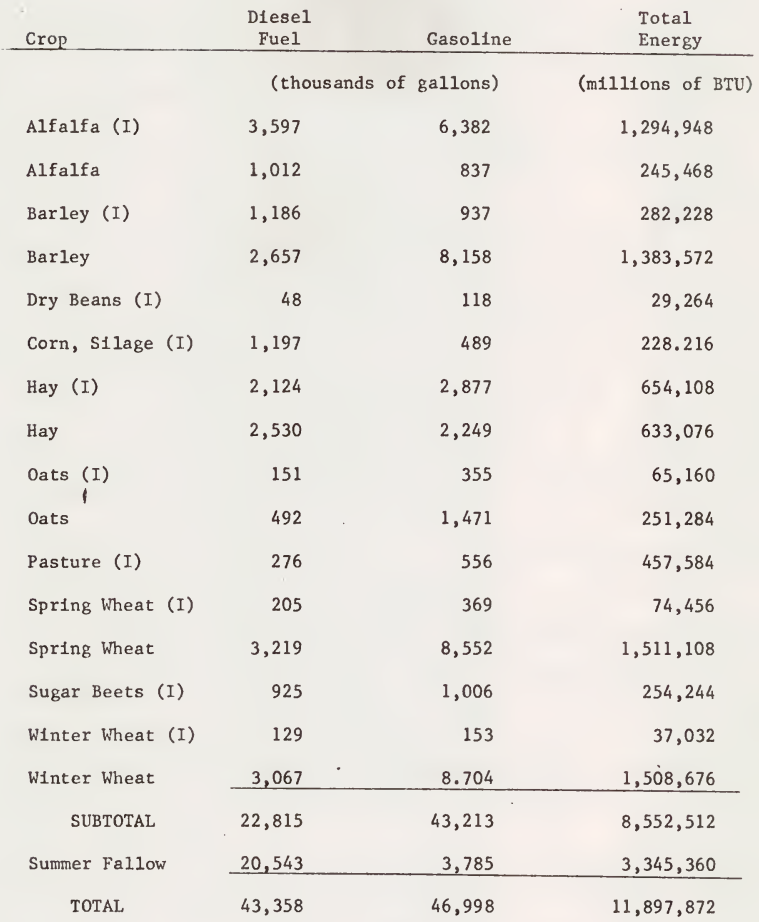

The symbol "I" indicates irrigated production. 
TABLE 2

Energy Requirements Per Acre for Major Crops in Montana (1973)

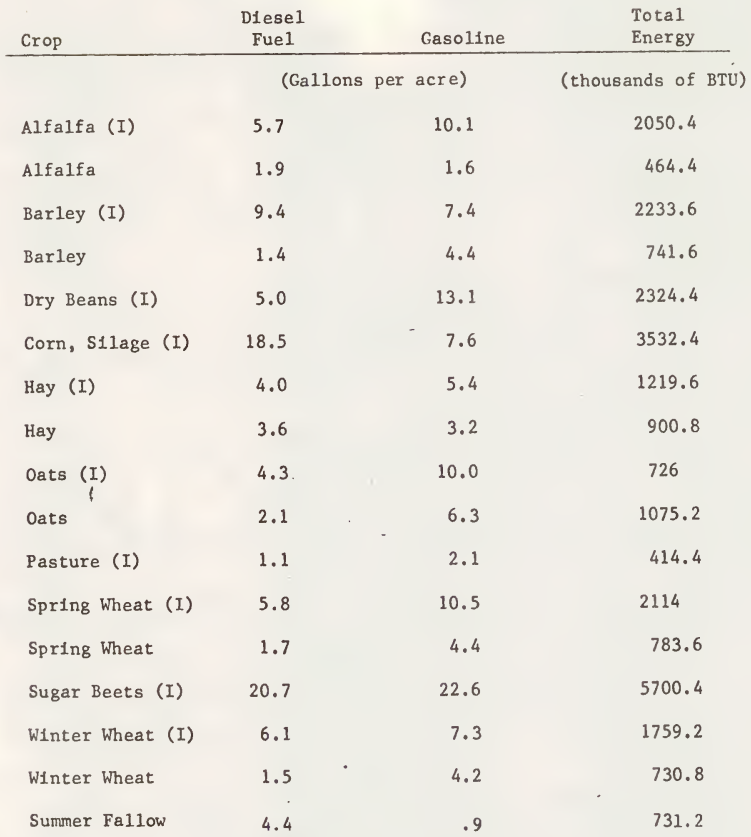

The symbol "I" Ind1cates 1rrigated production. 
EXPLANATION COVERING TOTAL FUELS USED

IN

MONTANA AGRICULTURAL PRODUCTION IN 1973

- Methods to compile the following information are explained below; not all information pertinent to the crop types is available in our office at this time. This nakes it necessary to estimate in some cases.

Fuel use, gallons per acre are treated in the following manner-some general information includes:

L. P. gas was not included due to limited use for farm production.

Iowa State University Weekly Weather and Crop Bulletin of June 4, 1974, was used to estimate farm fuel requirements for crop production and livestock operations.

Montana Crop \& Livestock Reporting Service Bulletin, of March 19th, 1974, was used for 1973 acres planted for all crops.

Montana Agricultural Statistics, Volume \#14, 1970 and 1971 was used for the livestock census used in report.

Diesel powered tractors and equipment consume approximately $27 \%$ less fuel than gasoline power, (Information Source: 1973 Agricultural ${ }_{1}$ Engineers (Nearbook), to preform the same work.

Inquiry was made in state concerning the split of diesel -vsgasoline ratio. The conclusions are dependent in the area questioned. The areas that are primarily cattle and hay operations are heavy users of gas rather than diesel. The areas that are primarily dryland wheat operations are primary users of diesel, due to the progression to large diesel powered tractors and combines.

The Billings area seems to meet a balance of irrigated, dryland and cattle operations. The polling in this area ran near a $60 \%$ gasoline and $40 \%$ diesel split in total usage. I feel that the $60-40$ ratio is probably close to the average for purposes of comparison. I have shown the 50-50 split also.

Sugarbeet planting and harvesting was not covered by the fuel bulletin. Due to my experience with beet production and corn silage production, it was determined that the corn silage type of crop covered by the bulletin would closely meet the demands of beet crops. 
Dry bean crop was treated in the same category as soybeans.

Hay--native or grain type, which of course are cut only once per seasion; but yield more tonnage per cut, were included with the three cutting hay's that are in a category of being bailed. Haylage with three cuttings chopped, consume one-third more fuel to harvest! The amount of haylage harvested could probably off-set the difference of one cutting native or grain hay -vs- three cutting bailed hay fuel needs. Fuel needs for the one cut hay are not much less than three cut hay, due to greater yield of tonnage per cut.

Livestock Industry fuel needs were not asked for in the request; but due to the bulletin providing data, it is included, Certainly subject to disapproval or arguement, I have taken the ratio of $75 \%$ gas and $25 \%$ diesel as the split for livestock productions. It seems that this operation would consume much more gasoline than diesel. 
ESTIMATE OF FUEL BURNED FOR CROP AND LIVESTOCK PRODUCTION UNDER AVERAGE CONDITIONS

$8 / 74$ - M. 0. Mortensen

LIVESTOCK

Sheep - 1972

' Hogs - 1971

245,000

All Cattle - $1972 \quad 3,165,000$
950,000

, 000

.40 P.U.
Montana

FUEL USED PER UNIT GASOLINE

(GALLONS)

.60 P.U.

DIESEL

(GALLONS)

.45 P.U.
TOTAL FUEL USED GASOLINE

(GALLONS)

570,000

DIESEL

(GALLONS)

427,500

98,000

73,500

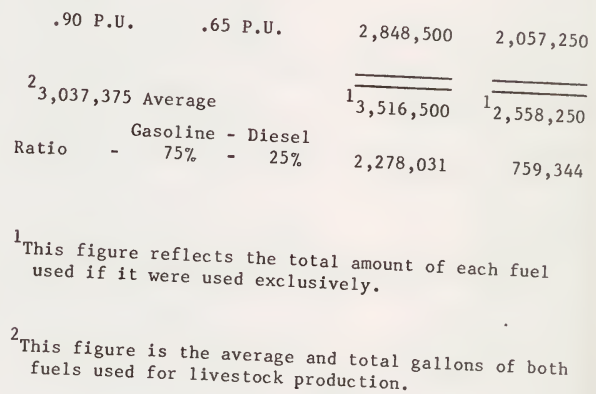

1

This figure reflects the total amount of each fuel
used if it were used exclusively.

2 This figure is the average and total gallons of both
fuels used for livestock production. 
$8 / 74$ - M. 0. Mortensen

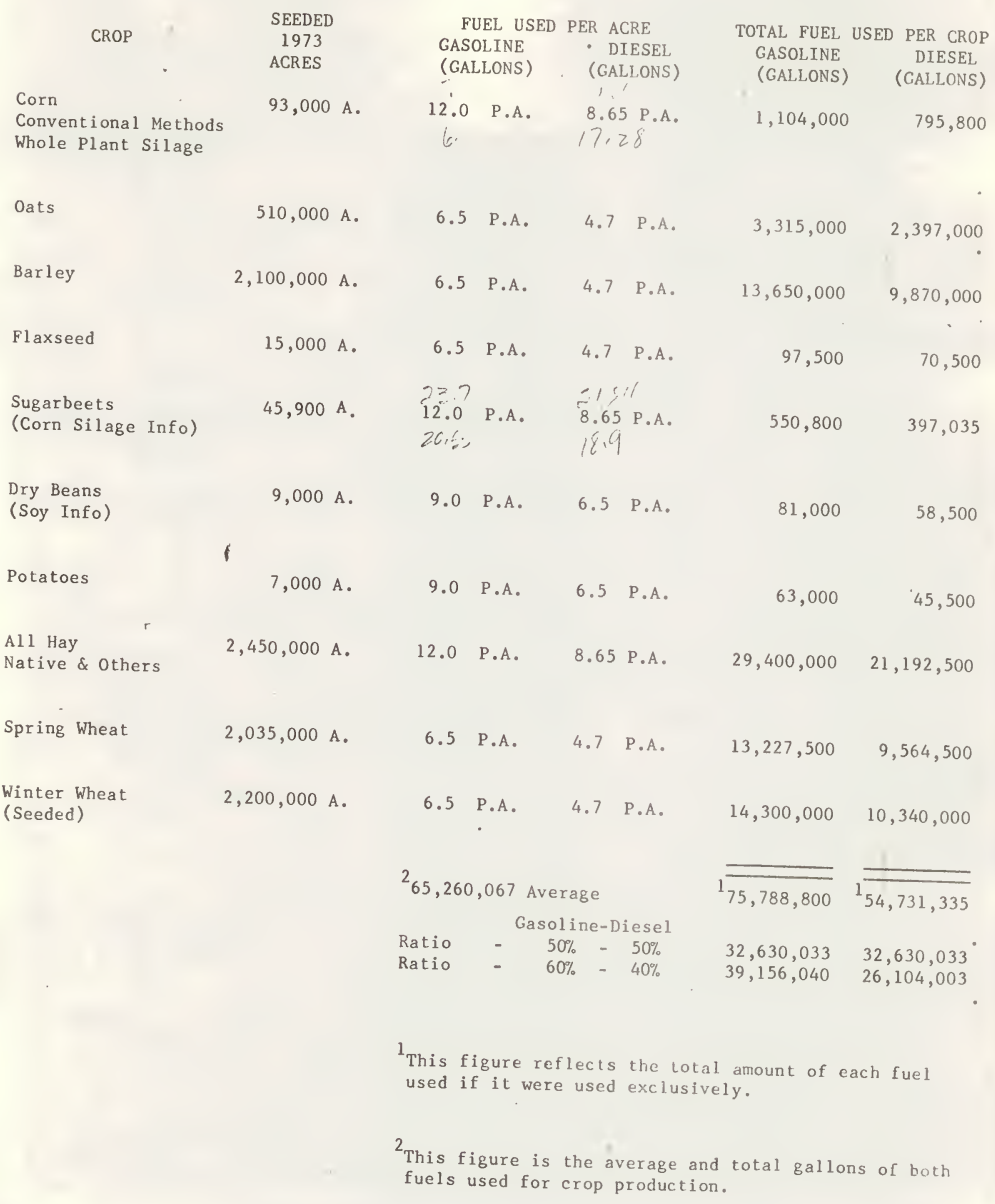


Attachment 4

information from John Clark, Research Division, Mont. Department of Revenue
Fiscal Year

$197,0-71$

- $1971-72$

. $19,72-73$

$1973-74$

$1974 \cdot 75$
Total

GALLONS

FOR WHICH

REFUNDS WERE

MADE

$31,035,031$

$27,385,428 *$

$34,724,1.41$

$32,472,82,3$

$31,503,864 \neq$

* A Sigi

A SIGNIFICANT NUMBER OF CIAIMS FOR FISLAL 197I-72

K'ERE NUTT PROCESSED UNTHL THE NEXT FISLAL YEAR (1972-73)

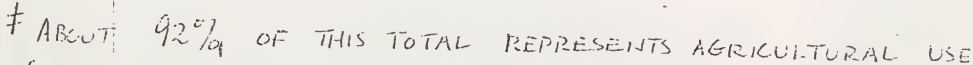
(DURING IG74-75 THERE WERE APPROXINATELY IDOCC CLANUANTS)

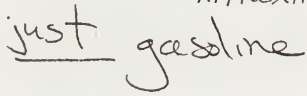


On 2-25-75 I contacted Mr. Dick Meyers from Montana State Agriculture Department concerning volumes of gasoline used by agriculture in 1972, 1973 and 1974 .

Mr. Meyers returned the following information based on the figures of an . average of 13,000 reporting farms:

1. In 1972 there were approximately 25,500 farms in Montana. Based on the above average, their direct gasoline use was $28,856,000$ gallons.

2. In 1973 there were approximately 25,100 farms in Montana. Based on the above average, their direct gasoline use was $26,544,000$ gallons.

3. In 1974 there were approximately 24,900 farms in Montana. Based on the above average, their direct gasoline useage was 34,502,000 gallons.

4. In 1975 , there are 24,600 farms in Montana.

Sincerely,

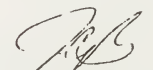

John C. Sraunbeck.

A. F. A. 0.

$\mathrm{JCB}: \mathrm{mt}$ 
